Published in: Folia Geobotanica 48 (2013): 209-227

Copy edited version is available in the publisher's homepage:

http://link.springer.com/article/10.1007\%2Fs12224-012-9142-0

\title{
Composition and Diversity of Lawn Flora in Differently Managed Village Yards - A Case Study from Southwestern Hungary
}

\author{
R.W. Pal ${ }^{\mathrm{a}^{*}}$, S. Csete ${ }^{\mathrm{a}}$, Z. Botta-Dukát ${ }^{\mathrm{b}} ;$ G. Pinke ${ }^{\mathrm{c}}$
}

anniversity of Pécs, Faculty of Sciences, Institute of Biology, H-7624 Pécs, Ifjúság u. 6, Hungary

${ }^{\mathrm{b}}$ Institute of Ecology and Botany, Hungarian Academy of Sciences, H-2163 Vácrátót, Alkotmány u. 2-4, Hungary

${ }^{c}$ University of West Hungary, Faculty of Agricultural and Food Sciences, Department of Botany, H-9200 Mosonmagyaróvár, Vár 2, Hungary

* Corresponding author: University of Pécs, Faculty of Sciences, Institute of Biology, H-7624 Pécs, Ifjúság u. 6, Hungary

Tel: +36 72 503600/4864; Fax: +36 72501520

E-mail address: palr@gamma.ttk.pte.hu

\begin{abstract}
Traditionally managed village yards have been disappearing from the CentralEuropean countryside. Their lawn flora is likely to provide a unique habitat for many plants that are adapted to this environment. Composition of lawn flora was investigated in differently managed village yards (i.e., regularly mown and regularly trampled yards, poultry yards, paved yards) in southwestern Hungary. The main goal of the study was to detect the impacts of these different management regimes on the composition and diversity of the vegetation. In total, $2401-\mathrm{m}^{2}$ plots were sampled in 60 yards ranging from $80 \mathrm{~m}^{2}$ to $5000 \mathrm{~m}^{2}$. In the redundancy analysis, eight significant variables (degree of southness, slope, age, total size of yards; mowing, trampling and grazing regime; and the number of dogs) explained $16 \%$ of the total variation in species data. The most diverse flora across yards was detected in the paved ones, and their stands also proved to be the most compositionally distinctive. In contrast, presence of domestic animals can contribute to local species loss as well as to a decrease in within-yard-type variability. These results highlight the importance of certain anthropogenic disturbances in maintaining high plant diversity, but also underline the crucial role of small-scale land management practices in rural environments.
\end{abstract}

Keywords Anthropogenic disturbance, Grazing, mowing, Ruderal vegetation, Trampling

Plant nomenclature Simon (2000)

\section{Introduction}

Many European countries have been affected by the processes of rural depopulation in the last decades (Pinilla et al. 2008; Ouředníček et al. 2011). Depopulation of small villages is also a 
major problem in Hungary with the most serious consequences of $i$ ) disappearance of traditional land use, the ii) abandonment of natural and man-made environments, iii) rapid degradation of land aesthetic value and $i v$ ) the spread of invasive or non-indigenous weeds (Pullin et al. 2009). As a result of globalization and modernization, the number of selfsupporting vegetable gardens and traditionally-used yards has been decreasing in villages. Those remaining serve mainly ornamental purposes and have thus became more uniform (Kapitány and Kapitány 2005). This homogenization can be associated with the decline of former village flora and vegetation, leading to a process, in which many species and vegetation types are becoming rare and endangered. This trend - which is now characteristic of many European countries - is most likely attributed to changing land-management practices, socio-economic structure and in aesthetic motivations of village inhabitants (Grosse-Brauckmann 1953; Hejný 1973; Bergmeier 1983; Wittig 1984; Kopecký 1986; Pyšek 1992; Wittig 2002; Siebert 2004; Lososová and Simonová 2008). Nevertheless, in some settlements of Hungary there are still a few traditional yards that are utilized in various ways and they should be explored and studied while they still exist.

Yards were crucial units of former agricultural village properties, and served basically as service areas between buildings. These usually fenced or walled, open-air sections were directly adjacent to the house and were used for threshing of crops; loading of firewood, fodder and manure; and raising of smaller animals (Balassa 1997). Currently, yards typically consist of paved sections, vegetable /flower beds and grassy or weedy vegetated sections (lawns). The relative proportion of these three sections can vary considerably; sometimes the entire yard is covered with cobblestones, while others consist entirely of lawn vegetation. Lawns can be planted or spontaneously arising from locally available plant species and may be managed or left unmanaged. The vegetation of these ruderal habitats sharply differs from arable fields (Šilc 2010). Species richness and composition of Central European urban floras are significantly affected by urban habitat types (Lososová et al. 2011). It was shown that species composition and richness of lawns in village yards is strongly influenced by local climate, intensity of use, lawn size and the circumstances of the life and work of human and domestic animals and also by socio-economic factors (Wattendorf 1997; Bergmeier 1990; Thompson et al. 2004; Smith et al. 2006; Lubbe et al. 2010). Despite the crucial importance of these factors in determining lawn floras, we know of no study that investigates how species composition and diversity are affected by differently managed yard types.

Davies et al. (2009) demonstrated that domestic gardens play a substantial role in maintaining, and enhancing biodiversity. A study of Thompson et al. (2003) demonstrated that urban domestic gardens in the UK are diverse habitats containing $67 \%$ of alien plant species. Most dominant lawn species in such habitats, however, are still native plants (Thompson et al. 2004, 2005). Loram et al. (2008) suggested that many elements of natural vegetation can still be found in these anthropogenic habitats filtering the local flora.

Lawn flora is mainly recruited from ruderal weeds and grassland species, can comprise a high proportion of natural elements of the local vegetation within the close vicinity of the households, and is less dependent on the direct human activity (Wattendorf 1997). Consequently, lawns are a suitable for investigating the impacts of human activity on vegetation in rural areas. In our study we have sought answers to the following questions: (1) How do differently managed yard types differ in terms of their floristic composition? (2) What are the main factors determining the composition of village yard floras? (3) What are the factors that influence diversity in different yards types?

\section{Methods}

Study Area 
The village of Aranyosgadány, typical for those in southwestern Hungary $\left(46^{\circ} 00^{\prime} \mathrm{N}\right.$, $18^{\circ} 07^{\prime} \mathrm{E}$ ), was selected as the study area because both regularly mown modern lawns and a variety of traditional yard managing systems are still in use. The region is hilly $(120-180 \mathrm{~m})$ with an average elevation of $150 \mathrm{~m}$. Mean annual precipitation is $650-700 \mathrm{~mm}$ and mean annual temperature is $10-11^{\circ} \mathrm{C}$ (averages between 1971-2000) (Bihari et al. 2009). The village is situated about $10 \mathrm{~km}$ southwest of the city of Pécs, and it is mainly surrounded by agricultural land, with some grass- and woodlands present. The administrative boundaries of the village enclose an area of approximately $7 \mathrm{~km}^{2}$. The number of inhabitants is 334 and the population density is 40.44 people $/ \mathrm{km}^{2}$. The study was carried out in the yards of 60 private, owner-occupied houses. Yards were selected from a pool of 165 householders who had either volunteered or were requested to participate in the study. Properties were between 20 and 150 years old and ranged from $80-5,000 \mathrm{~m}^{2}$. The largest part of the yards was covered by spontaneously-occurring vegetation; however, there were many sown lawns as well. Soil samples were collected at each yard, with $\mathrm{pH}$ values (in $\mathrm{KCl}$ ) ranging from 6.4-7.5. No geological differences were detected between the study sites in terms of parent material, and loamy soil was characteristic for the yards.

\section{Survey Method}

Lawn flora was assessed in four randomly selected $1-\mathrm{m}^{2}$ plots at each yard regardless of their size. Each plot was located according to randomly generated coordinates considering the location of the yard gate as the origo. In total 240 plots were sampled where the percentage cover of each species were recorded, and in addition, a complete list was made of all vascular plant taxa present in the yard (total species richness). Regularly cultivated surfaces, like flower beds, and kitchen gardens were avoided. The yards represented the typical land-use types within the village. Four main usage types could be separated during the surveys (Fig. 1): regularly mown yards (mown in every second to fourth week; 80 plots), regularly trampled yards (heavily compacted by vehicles and human, usually uncut; 48 plots), poultry yards (used for raising poultry; 56 plots), paved yards (yard surface was covered by large stones or bricks; 56 plots). The whole dataset was collected in July 2007.

For each yard, we recorded two geographical variables (degree of southness, slope) and the soil $\mathrm{pH}$. Other abiotic variables were not collected because of their presumed homogeneity in the surveyed settlement. Only the degree of southness, slope and soil $\mathrm{pH}$ varied remarkably providing different microenvironments and edaphic conditions for the vegetation. Age of the yard (established from owner interviews), size of the yard, disturbance regime (e.g., mowing, trampling, grazing), number and type of animals (e.g., dog, cat, horse, poultry), and the main character of the yards were also recorded (e.g., paved, non-paved). These variables refer to the management factors in a wider sense and were constant or regular and they obviously influenced the plant species composition and the development of different vegetation types in the yards. The percentage coverage of vegetation within the four $1-\mathrm{m}^{2}$ plots, and neighborhood (the neighboring surface type of the $1-\mathrm{m}^{2}$ plots) were also collected as important characteristics of the openness of the stands, and in terms of the potential adjacent species pool. The levels of trampling and mowing were estimated on a 4-category scale (none, light, medium, strong) because they were uniformly valid for the entire area. Grazing was recorded as a binary variable as it was usually patchy, and a suitable scale could not be established. Taxonomic nomenclature follows Simon (2000). Alien plant species status was gained from Balogh et al. (2004).

\section{Data Analysis}


The plot data were entered in TURBOVEG database (Hennekens and Schaminée 2001). Data analyses were performed using Past 2.04 (Hammer et al. 2001) and R (R Development Core Team 2009), using the vegan 2.0-2 (Oksanen et al. 2009) package. For each species, frequency and abundance were calculated in each subset of plots that belonged to differently managed yards.

Species richness, number of aliens, forbs and graminoids of the yard types was compared using sample-based rarefaction curves (Gotelli and Colwell 2001) where the yard with the fewest samples taken (trampled with 48 plots) was used as the basis of rarefying (resulting in values with decimals). Plot diversity was measured using the Shannon diversity index. The evenness of the species abundance distribution was calculated by the ratio of diversity values and their theoretical maximum at the given species richness, as suggested by Pielou (Magurran 2004). Four categories of yards (mown, trampled, paved and poultry yards) were compared based on species density, diversity and evenness values from a Kruskal-Wallis test and a subsequent Bonferroni corrected Mann-Whitney U test. To measure dominance as a function of competition in each yard category, we used the ratio of the abundance of the most dominant species and the summarized abundance of all the species occurring in a particular plot (Crawley 1997). Beta diversity was calculated using a modified Whittaker's measure as described by Harrison et al. (1992). This measure is neither sensitive to differences in sample size nor to false species turnover due to unequal species density of the compared sample units (Magurran 2004):

$\beta_{\mathrm{H} 2}=\left\{\left[\left(\mathrm{S} / \alpha_{\max }\right)-1\right] /(\mathrm{N}-1)\right\} \times 100$

$S$ refers to the pooled species number of the compared sample units while $\alpha_{\max }$ is the species richness of the richest sample unit. $\mathrm{N}$ refers to the number of the compared samples. We used this simple equation to describe beta diversity at two different scales. The finer scale was at yard level, where species richness of the 4 plots taken in the same yard was compared to the species richness of the yard itself. Here at yard scale, $\mathrm{S}$ is the pooled species richness of the 4 plots taken in the same yard, $\alpha_{\max }$ is the maximum species richness of these plots, $\mathrm{N}$ is equal to 4. The larger scale was at the level of management types. Here, species richness of each yard belonging to the same management type was compared to the species richness of the management type itself. In this case, $S$ is the pooled species richness of the yards managed in the same way, $\alpha_{\max }$ is the maximum species richness of these yards and $\mathrm{N}$ is the number of the yards proved to belong to the same management type.

Mean similarity among plots within a yard type were measured using the Bray-Curtis index. The Bray-Curtis index shows textural similarities where flora lists are weighted by the cover of the species. To detect significant differences among these similarities, we used the same nonparametric methods mentioned above.

Unconstrained ordinations of plots were done using metric multidimensional scaling with binary data, a complement of Sørensen similarity as distance measure (Podani 2001). The effects of 13 potential explanatory variables representing geographic variables (southness, slope), pedological conditions (soil pH), yard characteristics (age and size of yard), disturbance regime (anthropogenic disturbance type and degree, disturbance history, presence /type and number/ of domestic animals) and plot characteristics (shade percent, neighborhood, total vegetation cover, height of vegetation) were tested using redundancy analysis (RDA). Prior to the analysis, species occurrence data were Hellinger transformed (Legendre and Gallagher 2001) and ordinal data (trampling, mowing) were transformed to numbers from 0 to 3 following the methods of ter Braak and Verdonschot (1995). First backward variable selection was applied to eliminate the superfluous explanatory variables, and then the marginal effect of variables in the reduced model was tested using a permutation test. The significance level was set to $5 \%$ and maximum of allowed type II error rate was $10 \%$. The 
number of required permutation steps was determined according to these settings. The explained variation was partitioned into three groups of explanatory variables (Peres-Neto et al. 2006): (1) slope and southness, (2) age and size, (3) disturbance regime, and partial effects of the variable groups were tested using permutation tests.

\section{Results}

\section{Species Richness and Diversity}

The entire yard flora consisted of 150 species, of which 106 were found in the $1-\mathrm{m}^{2}$ plots. Among these 106 species, 28 occurred only once and there was no species that occurred in every single plot. There was a weak positive correlation between the total species richness of yards and their log area (Fig. 2). Striking differences in the rarefied pooled species number were detected among the yard types (Table 1), where mown and paved yards had the highest values (61.7 and 60 vascular plant species, respectively). Trampled and poultry yards had more species-poor stands with around 47 and 40.7 species with no significant difference between them (Fig. 3). The number of alien species present was similar in each yard type except for paved ones, where there were nearly twice as many present (11.4 species) (Table 1).

Most lawn species were forbs (80\%); only $20 \%$ were graminoids. The proportion of these two groups in the species composition independent of the management types was stable. In contrast, for abundance weighted textural data, the ratio of forbs and grasses changed in accordance with the types of management. Poultry yards were dominated almost exclusively by forbs; hence grasses were represented only with $3.25 \%$. Of the four management types, only mown yards had graminoids as relatively dominant (Table 2).

There were only slight differences among the differently managed yards with respect to the most frequent as well as the most abundant species (Table 3). In the case of mown, poultry and trampled yards, the most frequent species had the highest relative cover. Even in the paved yards, the two lists overlapped partially, but the order of the species was completely different. The highest cover values of the paved yards had a much smaller range (from 1.73 to 7.65), and that of the other types (1.21 to 66.43). In the paved yards, the frequency of the most common species reached a maximum of 0.43 , whereas in the poultry one it was 0.46 and in the trampled one 0.51 . The most frequent species of mown yards appeared in 72 plots out of 100 , implying a more uniform feature of this yard type.

Significant differences were found in all the possible relations among the differently managed yards in terms of their species densities (Table 4). Although considerable variances in the mean species numbers per plot were detected, paved yards were significantly more species-rich (10.1 species per plot in average), while mown, trampled and poultry yards showed lower values: 8.46, 6.96 and 5.46 species per plot, respectively. The minimum value was the lowest in the case of poultry and trampled yards (2 species per plot), and the maximum value did not exceed 12 species per plot. Mown and paved yards showed not only higher species density in general, but the minimum as well as the maximum values were also higher (3-3, 15-17 species per plot, respectively).

Paved yards were also the most diverse in terms of Shannon index, which was consistent with the results using species density (Table 4). Despite having higher numbers of species present, the diversity values in mown yards were not different from trampled yards and their evenness was also similar. Poultry yards showed an overall lack of species, with the lowest Shannon diversity and evenness values.

Dominance values (Table 4) can refer to the competition occurring among plant populations in the sampled vegetation units. Higher dominance values indicate greater disproportion among plant abundances, likely due to the presence of a strong competitor. 
Poultry yards showed the highest dominance values with usually one dominant species with more than $85 \%$ cover, but more than half of the dataset had values ranging from $80 \%$ to $95 \%$. We found no yards of this kind with dominance values below $65 \%$. Mown yards with dominance values of $67.2 \%$ and trampled ones with $68.8 \%$ were less competitive on average. Paved yards not only showed the lowest values in terms of maximum and minimum, they also had a dramatically lower average dominance value that was nearly two times smaller than that of the poultry yards $(45.1 \%)$.

When examining the species richness of plots within yards, high $\beta$-diversity was measured in the case of mown and paved yards, lower in trampled ones while the lowest value was calculated in poultry yards. This difference in yard level $\beta$-diversity indicates more homogenous vegetation in poultry yards similarly to the result of larger scale (yard type-level) comparison where these yards proved to be the less variable within their type as well (Table 4).

Large differences inthe species composition of plots within a yard type, were measured in each yard type, with median values showing low similarities between $24 \%$ and $33 \%$ (Table 4). Poultry yards showed the lowest value (24\%), trampled the highest value (33\%, significantly differing from the rest of the types) while mown $(29 \%)$ and paved ( $28 \%$ ) yards were similar.

Within-yard-type textural similarity computed on the basis of abundance data from the four studied yard types showed significant differences (Table 4). Paved yards had the lowest average similarity values with an average of $22.5 \%$. Mown lawns showed slightly higher similarity, with not only a higher median value $(33 \%)$ but also greater variance in the similarity values. Trampled yards proved to be more uniform, where average similarity was higher than $51 \%$, while poultry yards showed the highest within-yard-type similarity with about $58 \%$ on average.

\section{Species Composition}

Differences were detected between regularly mown, paved and poultry yards. Trampled yards showed a remarkable overlap with poultry yards. Partial overlap also occurred between mown and paved yards in the indirect ordination (Fig. 4). Poultry yards not only differed from every other yard management types in terms of its species composition, but similarity among the poultry yard plots was also considerably high.

In the direct (canonical) ordination, step-wise variable selection removed the following variables from the model: the disturbance history of the yard; paving, neighborhood; shadow extent; number of horses and poultry; and soil $\mathrm{pH}$. All variables in the reduced model had significant marginal effects (Table 5). The RDA ordination diagram (Fig. 5) showed that the first axis corresponded to grazing, while the second axis mainly referred to trampling and mowing and to a lesser extent to the total size of the yard, number of dogs, southness, slope and age of the yard. The first axis explained $6.7 \%$ of the total variation in species data (50.9\% of the variation is explained by the first unconstrained axis), the first and second axes combined accounted for $11.6 \%$ of the total variation $(49.5 \%$ of the variation is explained by the first unconstrained axis).

The distribution of species scores along the first RDA axis indicates that the following species tolerate higher grazing regime: Amaranthus crispus, Matricaria chamomilla, Polygonum aviculare, Verbena officinalis (Fig. 5). In our experience these were the most common species in poultry yards. Lolium perenne, Plantago major and Trifolium repens are positively related to mowing regime, while Digitaria sanguinalis, Echinochloa crus-galli, Oxalis corniculata, Portulaca oleracea, Setaria viridis to trampling regime. These latter taxa were frequent in paved yards. 
Variation partitioning based on RDA (Fig. 6) revealed that the largest fraction $(10.52 \%)$ of variation in species composition can be explained by disturbance factors (mowing, trampling, grazing and number of dogs). $1.93 \%$ of the total variation was affected by geographical variables (southness, slope), while yard characteristics (age of the yard, total size of the yard) contributed only $0.94 \%$ to the explained variation but all three partial effects were significant.

\section{Discussion}

We found that four different yard management types (regularly mown and regularly trampled yards, poultry yards, paved yards) have distinctive types of vegetation. Our finding that variation in species composition was determined by the disturbance regime of the yards to a large extent supports the findings of Wattendorf (1997). There are numerous specific vegetation types worldwide governed by similar factors (Cilliers and Bredenkamp 2000).

The effects of the most important factors driving differences in species composition of the different yard types are listed below.

\section{Effects of Grazing}

Grazing, the continuous picking of hens, geese, ducks, guinea fowl and turkey that are kept together in the studied yards, was the most significant variable in determining the floras present. The vegetation of poultry yards is formed by the joint effect of the trampling and grazing of domestic fowl, which are often kept in greater density than the carrying capacity of the yard. Clark and Gage (1996) reported that different kinds of poultry have a different effect on weed vegetation. Intensive grazing by domestic geese brought large-scale degradation on perennial sandy grasslands and pastures (Török et al. 2008, 2009). Hermansen et al. (2004) suggest that poultry has an impact on the ground vegetation in the outdoor area. Hens remove the weeds and grasses and thereby diminish the need for mechanical weeding. Pavlu et al. (2006) demonstrated that continuous stocking resulted in a decrease of tall weedy grasses. Poultry yards in our study were extremely poor in grasses.

Poultry had a considerable effect on the lawn flora, greatly decreasing the species number as well as the evenness. This could also overshadow the effect of local disturbances (at yard level), resulting in a lower variance of within-yard-type diversity. In contrast, management such as trampling and mowing resulted in only medium species richness, and these management regimes likely less strongly determine the composition and diversity of the lawn stands. This allows local disturbances as well as to the local abiotic environment to modify the flora, hence the within-yard-type differences were higher.

Although Pykälä (2005) claimed that the presence of Plantago major and Polygonum aviculare is characteristic for cattle-grazed grasslands compared to abandoned ones. In our study these species were similarly common in all management types. According to our results, leafy dicotyledonous (e.g., Taraxacum officinale, Trifolium repens) and softer grass species (e.g., Lolium perenne, Digitaria sanguinalis) are likely to be favored by poultry in terms of choice feeding, leading to relatively lower frequencies and less dominance of these plants in this type of yards. The most frequent plants registered here are usually well adapted to high grazing pressure. Frequent and abundant species in poultry yards such as Plantago major are less favored because of their moderate palatability (Sagar and Harper 1964), while other species such as Glechoma hederacea, Matricaria chamomilla, Verbena officinalis and Polygonum aviculare contain sesquiterpene lactones that are highly irritating to gastrointestinal tract of animals, or bitter iridoid glycosides (Wichtl 2002; Kumar et al. 2005). In addition, poultry yards are compacted and consequently relatively drier due to frequent trampling by domestic fowl, leading to a flora similar to that of the trampled yards. 


\section{Effects of Mowing}

Mowing was the second most important variable that significantly determined the species composition of yard floras. That disturbance type was common in well-managed ornamental village yards, where vegetation was mowed approximately two times a month, depending greatly on the weather conditions. In addition to mowing, watering and fertilizing are also frequent and typical activities in such yards. These three principal treatments together control the species composition of lawns. These effects usually modify the founding effects of the original seed mixture often used for the establishment of these lawns. Unfortunately we have no information about the content of the mixtures used except for Lolium perenne, which is one of the most common constituents of commercial seed mixtures (Beddows 1967). This might be why Lolium perenne was the most frequent as well as dominant species in our study (Table 3), too, playing a basic role in determining the structure of the mown lawns as matrix species. In more than half of the yards of this kind Trifolium repens was a codominant species. This species forms large dense patches scattered randomly through the lawn successfully surviving in intense mowing conditions, as found also by Ilmarinen and Mikola (2009). Among forbs, Plantago major and Taraxacum officinale were both dominant and frequent, tolerating the high mowing regime to a great extent, in agreement with Ellenberg (1952) and Klotz and Briemle (2002). Occasionally Poa annua can also reach high dominance due to a variety of local disturbances (e.g., presence of dogs, rugged mowing, cover of litter, senescence of lawn). This finding agrees with the results of Thompson et al. (2004), who found increasing dominance of Роа аппиа parallel to growing disturbance next to houses.

Regularly mown yards were diverse habitats within the investigated yard types. Schippers and Joenje (2002) suggested that mowing and hay removal are a way to increase species diversity in grassland communities. However, Ilmarinen and Mikola (2009) found that mowing did not affect the species number, diversity or evenness of semi-natural grasslands as we also found in our study. Mown yards showed the same species-abundance diversity and evenness as trampled yards.

\section{Effects of Trampling}

Trampling also played an important role in determining the species composition of the village yards of our study. The soil surface of trampled yards was usually compacted by vehicles and by heavy treading. Because of this effect, vegetation was generally dwarf and therefore uncut. Zwaenepoel et al. (2006) found Poa annua, Plantago major and Polygonum aviculare to be the most frequent species dispersed by cars, and their seeds originate from compacted roads and road edges. Polygonum aviculare and Plantago major are known to be members of trampling communities (Knörzer 1987). In our study these species were also among the most frequent weeds in trampled yards. Compaction also tends to decrease the moisture availability for plants. Polygonum aviculare frequently occurs not only in trampled but also in moisture stressed or in localized droughty conditions (cf. Borhidi 1995). In trampled yards, regular mechanical disturbance of the upper soil layer can open small gaps that facilitate invasion by annual plants (e.g., Poa annua). In addition to cars and humans, typical sources of trampling could be the presence of dogs or other heavy animals. Interestingly, the number of dogs had also a significant effect on the species composition. That could be explained by the larger body size and the more vigorous activity of these animals representing a relatively important disturbance regime for the vegetation. We also investigated the effect of other pets present (e.g., cats) in the yards, but none was detected. 


\section{Effects of Paving}

Although paving as a variable was removed during the step-wise selection from the RDA model, paved yards should be discussed here because of their unique species richness and distinct species composition based on the ordination.

Despite being sparsely sprayed with herbicide, paved yards represent a unique habitat favoring high plant diversity due to special mechanisms selecting for a unique floristic composition. Paved yards can maintain not only the highest number of forbs and grasses in a $1-\mathrm{m}^{2}$ plot on average, but also support the highest evenness values among the differently managed yards. Joints between bricks and stones form narrow and shallow soil strips where many plant species can survive together separated from each other spatially by the bricks and the stone pieces. Partition of the space in this manner can contribute to decreasing the competitive ability of one or several dominant species and allows many others to exist even in close proximity. Weed composition in other European paved areas was affected by the intensity of use, joint width and light intensity (Fagot et al. 2011). According to the research of Grundy (2007) occurrence of weeds was correlated with pavement construction and materials, particularly the number of joints and bare soil.

Among the most frequent and dominant species, Convolvulus arvensis, Oxalis corniculata and Setaria viridis appear as associated with paved yards, while species that are common in other types of yards such as Plantago major and Lolium perenne are missing. According to Sagar and Harper (1964), these species are frequent in disturbed habitats. Plantago major needs low vegetation cover where it can reestablish itself easily by seeds. Although the vegetation cover is low in paved yards $( \pm 30 \%)$, the remaining space is covered with stones, which certainly are not suitable for plant growth.

Gaps are likely to form favorable habitats for several less disturbance-tolerant species because joints between the stones are well protected from disturbances (e.g., trampling). Oxalis corniculata for instance was a subdominant element of the investigated paved yards, similarly to the pavement flora found in the urban environment of other European cities (Čarni and Mucina 1998).

\section{Effects of Other Factors}

Besides the above-detailed disturbance factors the total variation was also affected by geographical variables (southness, slope), and yard characteristics (age of the yard, total size of the yard) to a lower extent. Ahrns (2009) argued that biogeographic parameters are crucial on a larger scale, while landscape-ecological determinants become relevant at a smaller extent in determining village floras. Our research comprised a smaller area, consequently the effect of variables like soil properties were less important and had no significant effect on the species composition probably due to their short gradient-lengths. Yet southness and slope proved to have a sufficient gradient length to show significant effect on the yard flora. According to this there were some species (e.g., Oxalis corniculata, Setaria viridis, Echinochloa crus-galli) that are more likely to occur in plain yards while there were no characteristic species preferring greater inclination.

Total size of the yards was a highly significant variable on the species composition presumably because it can have a considerable effect on the management regime of particular yards determining the species composition indirectly. We also tested relationship of yard size with the total species number and found similar results to those of Thompson et al. (2004) where species number were linearly correlated with the log of the lawn area. This may be due to lack of habitat diversity within the growing yard area. The entire yard area is managed in the same way, not allowing the development of different habitat formations, which is one of the main differences compared to the natural habitat types. 
Age of the yard was the least significant variable on the yards' species composition and it refers to a date when the house was built and the inhabitants have ever since managed their property. Loram et al. (2011) found that length of residency significantly decreased the proportion of native plant species per $\mathrm{m}^{2}$ garden area. We also found less species in older yards but the trend was not significant. This can be explained by the somewhat fewer age categories among yards and because we did not have younger ones (1-5 years), where, in the case of weed communities, the greatest changes could have taken place.

\section{Conservation Interest}

According to the phytosociological literature, most of the surveyed village yards can be classified in the alliance Malvion neglectae. This unit is more common in the Balkans and Eastern Europe but is disappearing in the Czech Republic (Lososová et al. 2009). It was shown that rural settlements can serve as refuge for unique flora and vegetation that are increasingly threatened by growing urbanization (Gutte 1986). We found only few plant species that are of conservation interest (e.g., Chenopodium murale, Chenopodium vulvaria, Potentilla supina, Sagina procumbens, Urtica urens). Village yards could play a crucial role in preserving these species and several others that are characteristic elements of these habitats. Chenopodium murale and Chenopodium vulvaria are enumerated among the endangered weed species of Hungary, their conservation status is VU (vulnerable) and NT (near threatened). These species were once characteristic elements of the traditional village flora, but are currently rapidly declining (Pinke et al. 2011). They have become threatened due to agricultural intensification associated with changes in rural lifestyle and in the socioeconomic structure of villages. This is related for instance to the decline in keeping small animals, cleaning and paving the streets and consequently the loss of habitats enriched by ammoniacal nitrogen (Lososová and Simonová 2008). Potentilla supina, Sagina procumbens and Urtica urens are not yet threatened species but are sporadically present or rare in Hungary (Király 2009).

In general, all studied yards consisted of predominantly native species. There were only 3 aliens (Amaranthus retroflexus, Conyza canadensis, Erigeron annuus) among the 25 most frequent vascular plants. The number of alien plant species was the highest in paved yards however, they were never so abundant to outcompete other native and archaeophyte weeds. Zerbe et al. (2004) also concluded that non-native species play a significant role in enhancing biological diversity in urban areas.

The traditional village yards we investigated are valuable due to their unique plant communities rather than for their particularly rare species. These communities, which cannot be found elsewhere, are also part of our cultural heritage.

\section{Conclusions}

The vegetation of the investigated village yards shows unique adaptations to traditional and modern forms of household management. We found that four different yard management types (mowing, trampling, grazing and paving) have distinctive types of vegetation. The most homogeneous samples were derived from yards with grazing activities. Grazing might comprise two, strong selective effects. Besides continuous trampling, poultry usually remove a lot of edible forbs and grasses hence decrease species richness and shift abundance equitability towards texturally more similar vegetation types. In these instances, several stress-tolerant plant species can dominate the plant assemblage forming a more homogeneous vegetation. Trampled yards are similar in terms of species composition to poultry yards partly because of the same selective mechanism (trampling) but it represents a less stressed environment due to the lack of continuous picking and removing of plants. 
Modern regularly mown yards are diverse habitats but they possess the most artificially selected species pool and were the only type where graminoids were dominant. This is the result of seed mixtures used for the establishment and the regular maintenance of lawns (mowing, weed control, fertilizing, watering). Paving supports the greatest species diversity because joints provide refuge for several plant species and this habitat reduces the competitive ability of dominant species and allows many others to exist even in close proximity.

The results of our study suggest that village yards can be diverse habitats and can harbor unique vegetation, where human activities have a great impact. Unfortunately in Hungary regularly mown yard types are continuously increasing in proportion at the expense of other traditionally managed yard types resulting in an overall homogenization of the rural environment.

Acknowledgements This work was supported by the Carpathes Nature Conservation Foundation and TÁMOP-4.2.2/B-10/1-2010-0029. We are grateful to the yard owners for the use of their property. Thanks to Prof. Sándor Bartha (Hungarian Academy of Sciences) for his help in initiating the project, to Emily Rauschert (St. Mary's College of Maryland) and to Prof. Paul Alaback (University of Montana) for useful comments and linguistic improvement of the text.

\section{References}

Ahrns C (2009) The ecological indication content of Central European village floras. Ecol Indicators 9:605-620

Balassa I (1997) Magyar néprajz nyolc kötetben 4. - Életmód-Anyagi kultúra. 3. Akadémiai Kiadó, Budapest

Balogh L, Dancza I, Király G (2004) A magyarországi neofitonok időszerü jegyzéke és besorolásuk inváziós szempontból. In Mihály B, Botta-Dukát Z (eds) Biológiai inváziók Magyarországon - Özönnövények. A KvVM Természetvédelmi Hivatalának tanulmánykötetei 9. TermészetBúVÁR Alapítvány Kiadó, Budapest, pp 61-92 (In Hungarian)

Beddows AR (1967) Biological Flora of the British Isles - Lolium perenne L. J Ecol 55:567587

Bergmeier E (1983) Bemerkungen zum Rückgang der Dorfflora am Beispiel der Gemeinde Kalletal (Kr. Lippe). Natur u Landschaft 58:330-332

Bergmeier E (1990) Spontanvegetation Nordgriechischer Bergdörfer. Folia Geobot 25:27-61

Bihari Z, Szalai S, Bozó L (2009) Natural environment - climate. In Kocsis K, Schweitzer F (eds) Hungary in maps. HAS Geographical Research Institute, Budapest, pp 45-50

Borhidi A (1995) Social behavior types, the naturalness and relative ecological indicator values of the higher plants in the Hungarian flora. Acta Bot Hung 39:97-181

Čarni A, Mucina L (1998) Vegetation of trampled soil dominated by C4 plants in Europe. $J$ Veg Sci 9:45-56

Cilliers SS, Bredenkamp GJ (2000) Vegetation of road verges on an urbanisation gradient in Potchefstroom, South Africa. Landscape Urban Plannig 46:217-239

Clark MS, Gage SH (1996) Effects of free-range chickens and geese on insect pests and weeds in an agro-ecosystems. Amer J Alternative Agric 11:39-47

Crawley MJ (1997) Plant ecology. Blackwell Science Ltd., Oxford

Davies ZG, Fuller RA, Loram A, Irvine KN, Sims V, Gaston KJ (2009) A national scale inventory of resource provision for biodiversity within domestic gardens. Biol Conservation 142:761-771 
Ellenberg H (1952) Meadows and pastures and their valuation with regard to site conditions. Ulmer Verlag, Stuttgart

Fagot M, De Cauwer B, Beeldens A, Boonen E, Bilcke R (2011) Weed flora in paved areas in relation to environment, pavement characteristics and weed control. Weed Res 51:650 660

Gotelli NJ, Colvell RK (2001) Quantifying biodiversity: procedures and pitfalls in the measurement and comparison of species richness. Ecol Lett 4:379-391

Grosse-Brauckmann G (1953) Über die Verbreitung ruderaler Dorfpflanzen innerhalb eines kleinen Gebietes. Mitt Florist-Soziol Arbeitsgem NF Stolzenau/Weser 4:5-10

Grundy AC (2007) Weed occurrence on pavements in the UK: The results from a survey of Leamington Spa. Aspects Appl Biol 82:175-182

Gutte P (1986) Dynamik der Ruderalvegetation in Siedlungsbereichen. Archiv für Naturschutz und Landschaftsforschung 26:99-104

Harrison S, Ross SJ, Lawton JH (1992) Beta diversity on geographic gradients in Britain. $J$ Anim Ecol 61:151-158

Hejný S (1973) Beitrag zur Charakteristik der Veränderung der Ruderalgesellschaften in Südböhmen. Acta Bot Akad Sci Hung 19:129-138

Hammer O, Harper DAT, Ryan PD (2001) PAST, Palaeontological Statistics software package for education and data analysis. Palaeontol Electronica 4:9

Hennekens SM, Schaminée JHJ (2001) TURBOVEG, a comprehensive database management system for vegetation data. J Veg Sci 12:589-591

Hermansen JE, Strudsholm K, Horsted K (2004) Integration of organic animal production into land use with special reference to swine and poultry. Livestock Prod Sci 90:11-26

Ilmarinen K, Mikola J (2009) Soil feedback does not explain mowing effects on vegetation structure in a semi-natural grassland. Acta Oecol 35:838-848

Klotz S, Briemle G (2002) BIOLFLOR-a data base on bio-ecological parameters of the flora of Germany. BfN-Schriftenvertrieb im Landwirtschaftsverlag, Münster

Kapitány Á, Kapitány G (2005) Globalisation, individualisation, modernisation, urbanisation and housing in Hungary. Társadalomkutatás 23:91-111

Király G (ed) (2009) New Hungarian herbal. The vascular plants of Hungary. Identification key. Aggteleki Nemzeti Park Igazgatóság, Jósvafó

Knörzer K-H (1987) Geschichte der synanthropen Vegetation von Köln. Kölner Jahrb. Vor- $u$ Frühgeschichte 20:271-388

Kopecký K (1986) Der Rückgang von Malvetum neglectae und die Sukzession auf seinen Standorten. Preslia 58:63-74

Kumar N, Singh B, Kaul VK, Ahuja PS (2005) Chemical and biological aspects of iridoid bearing plants of temperate region. Stud Nat Prod Chem 32:247-302

Legendre P, Gallagher EG (2001) Ecologically meaningfull transformations for ordination of species data. Oecologia 129:271-280

Loram A, Thomson K, Warren PH, Gaston KJ (2008) Urban domestic gardens (XII): The richness and composition of the flora in five UK cities. J Veg Sci 19:321-330

Loram A, Warren P, Thompson K, Gaston K (2011) Urban domestic gardens: The effects of human interventions on garden composition. Environm Managem 48:808-824.

Lososová Z, Simonová D (2008) Changes during the 20th century in species composition of synanthropic vegetation in Moravia (Czech Republic). Preslia 80:291-305

Lososová Z, Otýpková Z, Sádlo J, Láníková D (2009) Annual vegetation of arable land and ruderal habitats. In Chytrý M (ed) Vegetation of the Czech Republic - 2. Ruderal, weed, rock and scree vegetation. Academia, Praha, pp 73-202

Lososová Z, Chytrý M, Tichý L, Danihelka J, Fajmon K, Hájek O, Kintrová K, Kühn I, Láníková D, Otýpková Z, Rehořek V (2011) Native and alien floras in urban habitats: a 
comparison across 32 cities of central Europe. Global Ecol Biogeogr doi: 10.1111/j.14668238.2011.00704.x

Lubbe CS, Siebert SJ, Cilliers SS (2010) Political legacy of South Africa affects the plant diversity patterns of urban domestic gardens along a socio-economic gradient. Sci Res Essays 5:2900-2910

Magurran AE (2004) Measuring biological diversity. Blackwell Publishing, Oxford

Ouředníček M, Špačková P, Feřtrová M (2011) Changes in social milieu and quality of life in depopulating areas of the Czech Republic. Sociologický časopis 47:777-803

Oksanen J, Kindt R, Legendre P, O'Hara B, Simpson GL, Solymos P, Stevens MHH, Wagner H (2009) Vegan: Community Ecology Package. R package version 1.15-4. Available at: http://CRAN.R-project.org/package=vegan

Pavlů V, Gaisler J, Hejcman M, Pavlů L (2006) Effect of different grazing system on dynamics of grassland weedy species. J Pl Dis Protect 20:377-383

Peres-Neto P, Legendre P, Dray S, Borcard D (2006) Variation partioning of species data matrices: estimation and comparison of fractions. Ecology 87:2614-2625

Pinilla V, Ayuda MI, Sáez LA (2008) Rural depopulation and the migration turnaround in Mediterranean Western Europe: a case study of Aragon. J Rural Comm Developm 3:1-22

Pinke Gy, Király G, Barina Z, Mesterházy A, Balogh L, Csiky J, Schmotzer A, Molnár VA, Pál RW (2011) Assessment of endangered synanthropic plants of Hungary with special attention to arable weeds. Pl Biosyst 145:426-435

Podani J (2001) SYN-TAX (2000) Computer programs for data analysis in ecology and systematics, User's manual. Scientia Kiadó, Budapest

Pykälä J (2005) Plant species responses to cattle grazing in mesic semi-natural grassland. Agric Ecosyst Environm 108:109-117

Pyšek A (1992) Bemerkungen zum gegenwärtigen Stand der westböhmischen Ruderalvegetation. Folia Mus Rer Natur Bohem Occid 36:1-18

Pullin AS, Báldi A, Can OE, Dieterich M, Kati V, Livoreil B, Lövei G, Mihók B, Nevin O, Selva N, Sousa-Pinto I (2009) Conservation focus on Europe: Major conservation policy issues that need to be informed by Conservation Science. Conservation Biol 23:818-824

R Development Core Team (2009) $R$ : A language and environment for statistical computing. R Foundation for Statistical Computing, Vienna. Available at: http://www.R-project.org

Sagar GR, Harper JL (1964) Biological flora of the British Isles - Plantago major L. J Ecol 52:189-205

Schippers P, Joenje W (2002) Modelling the effect of fertiliser, mowing, disturbance and width on the biodiversity of plant communities of field boundaries. Agric Ecosyst Environm 93:351-365

Siebert SF (2004) Traditional agriculture and the conservation of biological diversity in Crete, Greece. Int J Agric Sustainability 2:109-117

Šilc U (2010) Synanthropic vegetation: pattern of various disturbances on life history traits. Acta Bot Croatia 69:215-227

Simon T (2000) A magyarországi edényes flóra határozója (Vascular flora of Hungary). Nemzeti Tankönyvkiadó, Budapest (In Hungarian)

Smith RM, Thompson K, Hodgson JG, Warren PH, Gatson KJ (2006) Urban domestic gardens (IX): Composition and richness of the vascular plant flora, and implications for native biodiversity. Biol Conservation 129:312-322

ter Braak CJF, Verdonschot PFM (1995) Canonical correspondence analysis and related multivariate methods in aquatic ecology. Aquatic Sci 57:255-289

Thompson K, Austin KC, Smith RM, Warren PH, Angold PG, Gaston KJ (2003) Urban domestic gardens (I): Putting small-scale plant diversity in context. J Veg Sci 14:71-78

Thompson K, Hodgson JG, Smith RM, Warren PH, Gaston KJ (2004) Urban domestic gardens (III): Composition and diversity of lawn floras. J Veg Sci 15:373-378 
Thompson K, Colsell S, Carpenter J, Smith RM, Warren PH, Gaston KJ (2005) Urban domestic gardens (VII): a preliminary survey of soil seed banks. Seed Sci Res 15:133141

Török P, Matus G, Papp M, Tóthmérész B (2008) Secondary succession of overgrazed Pannonian sandy grasslands. Preslia 80:73-85

Török P, Matus G, Papp M, Tóthmérész B (2009) Seed bank and vegetation development of sandy grasslands after goose breeding. Folia Geobot 44:31-46

Wattendorf P (1997) Influences of land-use on the structure of ruderal vegetation in the village of Lonja (Lonjsko Polje Nature Park/Croatia). Nat Croat 6:349-366

Wichtl M (2002) Teedrogen und Phytopharmaka - Ein Handbuch für die Praxis auf wissenschaftlicher Grundlage. WVG, Stuttgart

Wittig R (1984) Sterben die Dorfpflanzen aus? Ergebnisse einer umfassenden Untersuchung der Dorfflora in 180 Dörfen Nordheim-Westfalens. Der Gemeinderat 27:36-37

Wittig R (2002) Siedlungsvegetation. Ulmer Verlag, Stuttgart

Zerbe S, Choi, I, Kowarik I (2004) Characteristics and habitats of non-native plant species in the city of Chonju, southern Korea. Ecol Res 19:91-98

Zwaenepoel A, Roovers P, Hermy M (2006) Motor vehicles as vectors of plant species from road verges in a suburban environment. Basic Appl Ecol 7:83-93 
Table 1 Species numbers of different yards rarefied to the smallest sample size of 48 plots (rarefaction estimation)

\begin{tabular}{lcccc}
\hline \multicolumn{1}{c}{ Yard type } & $\begin{array}{c}\text { Total } \\
\text { species nr. }\end{array}$ & nr. of aliens & nr. of forbs & $\begin{array}{c}\text { nr. of } \\
\text { graminoids }\end{array}$ \\
\hline $\begin{array}{l}\text { Regularly mown } \\
\text { yards }\end{array}$ & 61.7 & 7.4 & 49.1 & 12.55 \\
$\begin{array}{l}\text { Regularly } \\
\text { trampled yards }\end{array}$ & 47 & 7 & 37 & 10 \\
$\begin{array}{l}\text { Poultry yards } \\
\text { (regularly grazed) }\end{array}$ & 40.7 & 6.0 & 33.5 & 7.3 \\
$\begin{array}{l}\text { Paved yards and } \\
\text { pavements }\end{array}$ & 60.0 & 11.4 & 48.15 & 11.85 \\
\hline
\end{tabular}

Table 2 Relative abundance of forbs and graminoids in differently managed yards

\begin{tabular}{lcccc}
\hline & Mown & Trampled & Poultry & Paved \\
\hline Forbs & 43.13 & 84.64 & 96.75 & 68.09 \\
Graminoids & 56.87 & 15.37 & 3.25 & 31.91 \\
\hline
\end{tabular}

Table 3 Frequent and abundant species of the differently managed yards

\begin{tabular}{|c|c|c|}
\hline Yard type & $\begin{array}{l}5 \text { most frequent species and } \\
\text { their frequency }\end{array}$ & $\begin{array}{l}5 \text { most abundant species and } \\
\text { their average cover }\end{array}$ \\
\hline $\begin{array}{l}\text { Regularly mown yards } \\
\text { (80 plots) }\end{array}$ & $\begin{array}{l}\text { Lolium perenne }(0.72) \\
\text { Plantago major }(0.64) \\
\text { Taraxacum officinale }(0.60) \\
\text { Trifolium repens }(0.55) \\
\text { Digitaria sanguinalis }(0.35) \\
\end{array}$ & $\begin{array}{l}\text { Lolium perenne }(40.86) \\
\text { Trifolium repens }(13.15) \\
\text { Poa annua }(6.79) \\
\text { Taraxacum officinale }(3.86) \\
\text { Plantago major }(3.37) \\
\end{array}$ \\
\hline $\begin{array}{l}\text { Regularly trampled yards } \\
\text { (48 plots) }\end{array}$ & $\begin{array}{l}\text { Polygonum aviculare }(0.46) \\
\text { Plantago major }(0.43) \\
\text { Lolium perenne }(0.36) \\
\text { Taraxacum officinale }(0.23) \\
\text { Poa annua }(0.23) \\
\end{array}$ & $\begin{array}{l}\text { Poygonum aviculare }(51.27) \\
\text { Lolium perenne }(10.16) \\
\text { Plantago major }(4.06) \\
\text { Portulaca oleracea }(2.32) \\
\text { Malva neglecta }(1.21) \\
\end{array}$ \\
\hline $\begin{array}{l}\text { Poultry yards (regularly grazed) } \\
\text { (56 plots) }\end{array}$ & $\begin{array}{l}\text { Polygonum aviculare }(0.51) \\
\text { Verbena officinalis }(0.30) \\
\text { Plantago major }(0.27) \\
\text { Matricaria chamomilla }(0.17) \\
\text { Poa annua }(0.15)\end{array}$ & $\begin{array}{l}\text { Polygonum aviculare }(66.43) \\
\text { Verbena officinalis }(6.15) \\
\text { Plantago major }(2.37) \\
\text { Lolium perenne }(2.25) \\
\text { Glechoma hederacea }(1.5)\end{array}$ \\
\hline $\begin{array}{l}\text { Paved yards } \\
\text { (56 plots) }\end{array}$ & $\begin{array}{l}\text { Digitaria sanguinalis }(0.43) \\
\text { Taraxacum officinale }(0.43) \\
\text { Polygonum aviculare }(0.42) \\
\text { Portulaca oleracea }(0.42) \\
\text { Convolvulus arvensis }(0.34)\end{array}$ & $\begin{array}{l}\text { Portulaca oleracea }(7.65) \\
\text { Polygonum aviculare }(3.91) \\
\text { Convolvulus arvensis }(2.13) \\
\text { Oxalis corniculata }(2.13) \\
\text { Setaria viridis }(1.73)\end{array}$ \\
\hline
\end{tabular}


Table 4 Species density, Shannon diversity (H'), Evenness (E), Dominance, Beta-diversity at yard level and at type level, floristic and textural similarity for different yard types. Within a row, numbers followed by the same letter are not significantly different on the basis of Kruskal-Wallis test)

\begin{tabular}{|c|c|c|c|c|c|c|}
\hline Yard type & $\begin{array}{c}\text { Regularly } \\
\text { mown } \\
\text { yards }\end{array}$ & $\begin{array}{c}\text { Regularly } \\
\text { trampled } \\
\text { yards }\end{array}$ & $\begin{array}{l}\text { Poultry } \\
\text { yards } \\
\text { (regularly } \\
\text { grazed) }\end{array}$ & $\begin{array}{c}\text { Paved } \\
\text { yards and } \\
\text { pavements }\end{array}$ & $\mathrm{H}$ & $P$ \\
\hline $\begin{array}{l}\text { Species } \\
\text { density }\end{array}$ & 8,46 a & $6,96 \mathrm{~b}$ & $5,46 \mathrm{c}$ & $10,1 \mathrm{~d}$ & 62.85 & $<0.05$ \\
\hline $\begin{array}{l}\text { Shannon } \\
\text { diversity (H') }\end{array}$ & $0,97 \mathrm{a}$ & $0,82 \mathrm{a}$ & $0,47 \mathrm{~b}$ & $1,58 \mathrm{c}$ & 74.97 & $<0.001$ \\
\hline $\begin{array}{l}\text { Evenness } \\
\text { (E) }\end{array}$ & $0,46 \mathrm{a}$ & $0,41 \mathrm{a}$ & $0,30 \mathrm{~b}$ & $0,68 \mathrm{c}$ & 96.03 & $<0.001$ \\
\hline Dominance & $67,2 \mathrm{a}$ & $68,8 \mathrm{a}$ & $85,5 \mathrm{~b}$ & $45,1 \mathrm{c}$ & 79.91 & $<0.001$ \\
\hline $\begin{array}{l}\text { Beta-diversity } \\
\text { at yard scale }\end{array}$ & $20,4 \mathrm{~b}$ & 15,9 a,b & $10,7 \mathrm{a}$ & $17,6 \mathrm{~b}$ & 9.08 & $<0.05$ \\
\hline $\begin{array}{l}\text { Beta-diversity } \\
\text { at type scale }\end{array}$ & 10,5 & 9,5 & 6,7 & 10,9 & - & - \\
\hline $\begin{array}{l}\text { Average } \\
\text { textural } \\
\text { similarity } \\
\text { (Bray-Curtis } \\
\text { index) }\end{array}$ & $0,33 \mathrm{a}$ & $0,51 \mathrm{~b}$ & $0,58 \mathrm{c}$ & $0,225 \mathrm{~d}$ & 1291 & $<0.001$ \\
\hline
\end{tabular}

Table 5 Marginal effect of each variable to the species composition. Probabilities of Type I error are estimated using a permutation test

\begin{tabular}{llll}
\hline Variable & Explained variation & $\boldsymbol{F}$-statistic & $\boldsymbol{P}$-value \\
\hline Grazing & 0.033 & 13.7241 & 0.005 \\
Mowing & 0.012 & 5.0960 & 0.005 \\
Trampling & 0.005 & 2.2450 & 0.005 \\
Slope & 0.010 & 4.2677 & 0.005 \\
Southness & 0.007 & 2.8105 & 0.005 \\
Dog nr & 0.006 & 2.4947 & 0.005 \\
Size total & 0.006 & 2.4358 & 0.005 \\
Age & 0.005 & 2.1164 & 0.010 \\
\hline
\end{tabular}



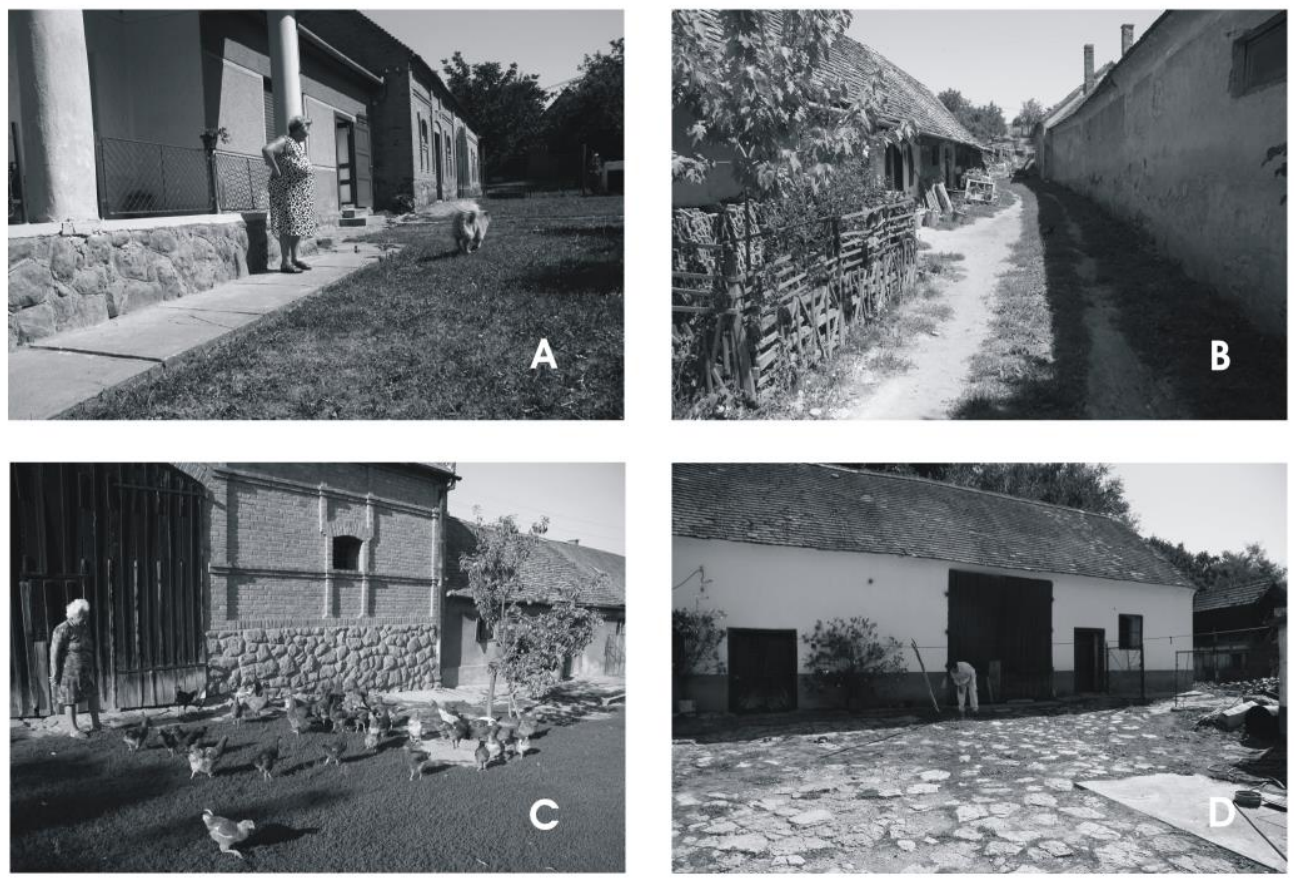

Fig. 1 The four different yard types from the village of Aranyosgadány (Hungary): A regularly mown yard, $\mathbf{B}$ regularly trampled yard, $\mathbf{C}$ poultry yard, $\mathbf{D}$ paved yard (photographs R.W. Pal)

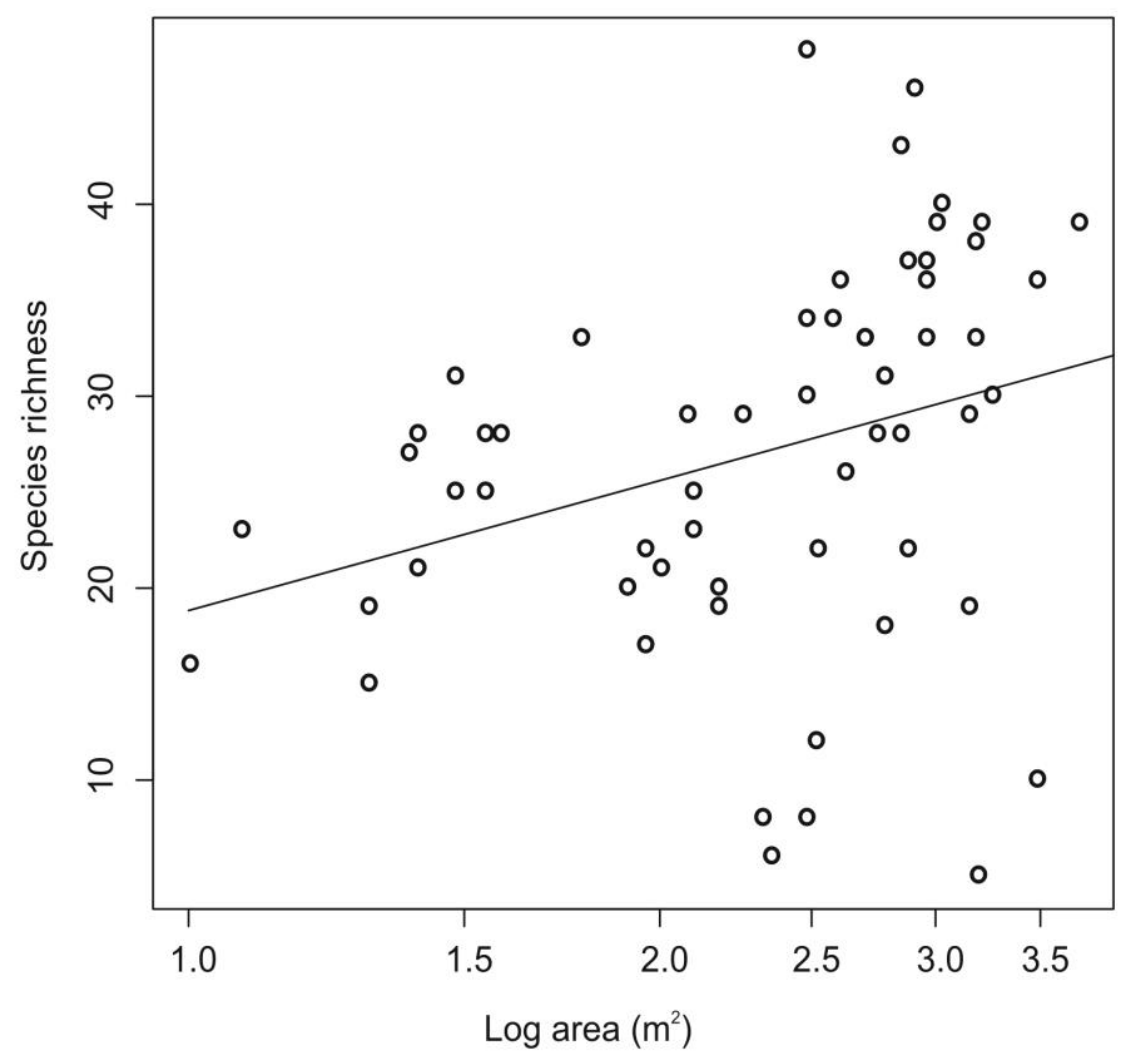

Fig. 2 Positive correlation was found between the size of the yards and their total species richness. $\left(F=6.378 ; t=2.525 ; P=0.0143 ; r^{2}=0.099\right)$ 


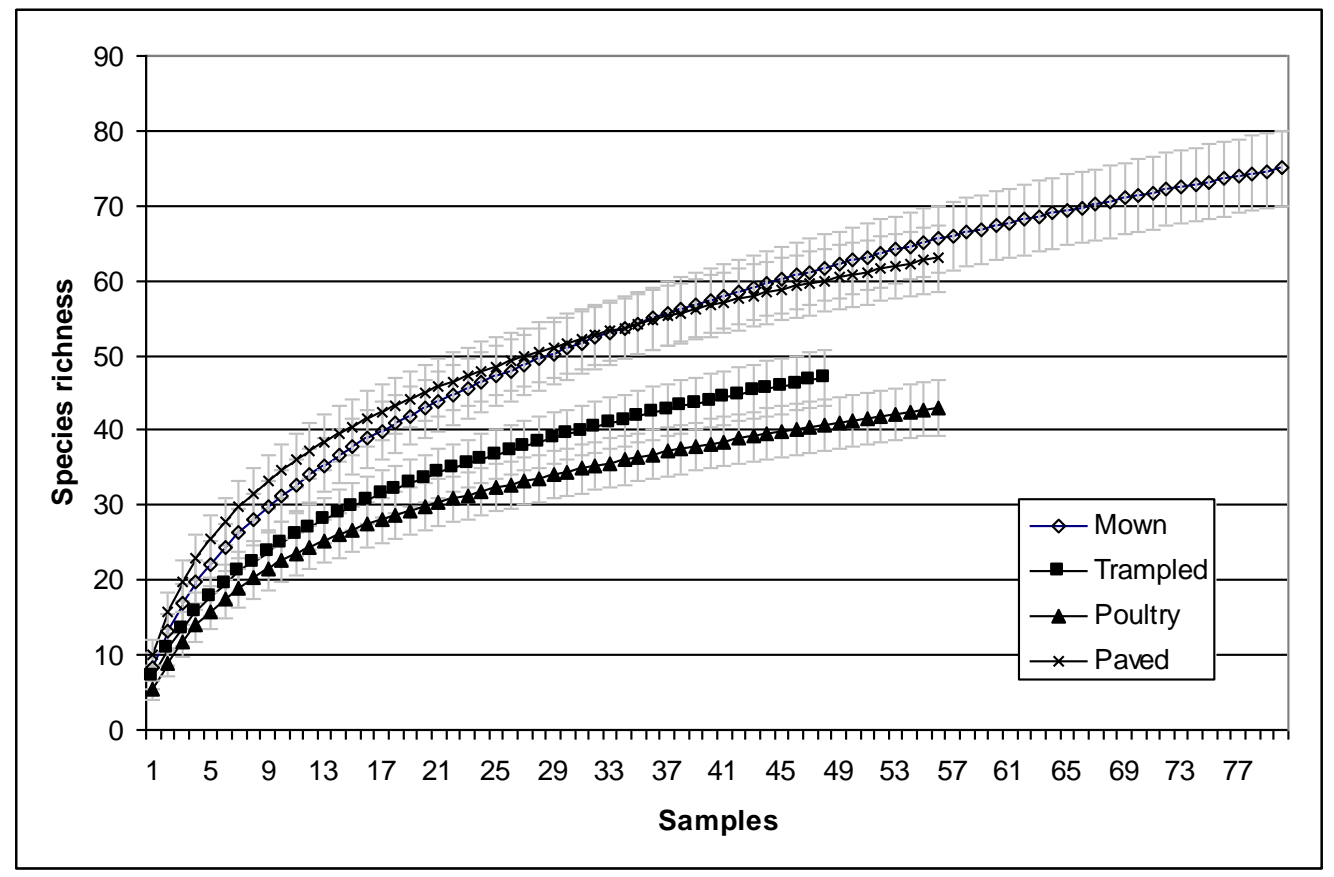

Fig. 3 Sample-based rarefaction curves of the four different yard types. Although none of the four curves reach their asymptotes, trampled and poultry yards tend to show lower species richness than mown and paved ones (mean species richness and 95\% confidence intervals based on repeated random re-sampling of the raw dataset)

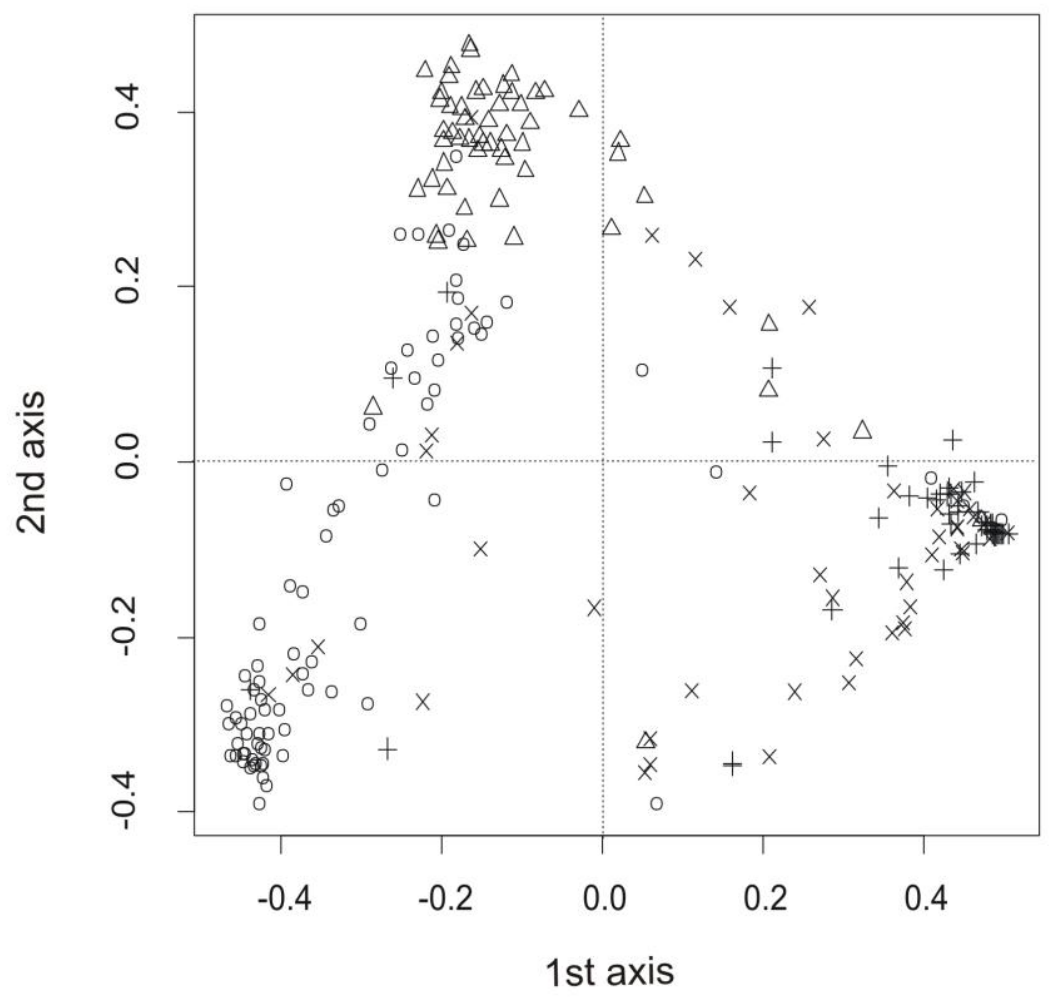

Fig. 4 Ordination diagram (Sørensen index) of the plots made in differently managed village yards ( $\circ-$ regularly mown yards, $\Delta-$ paved yards, +- poultry yards, $\times-$ trampled yards). First axis contains $31.84 \%$ of the information while the second one holds $16.2 \%$ 


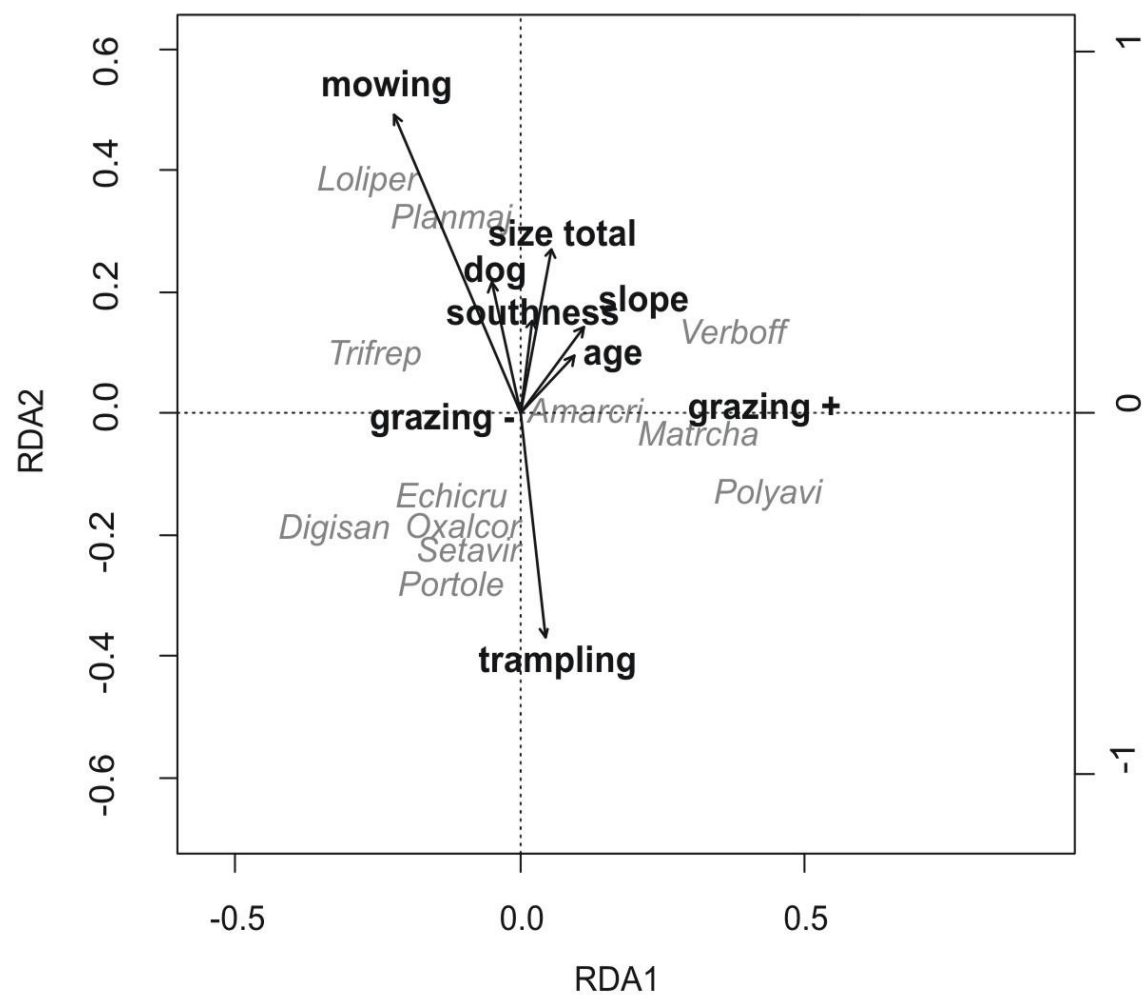

Fig. 5 RDA analyses of the dataset (ecological factors are explaining $16 \%$ of all variability, the first axis explains $6.7 \%$, the first two $11.6 \%$ ). Ordination of explanatory variables and of species (only species with the highest fit (explained variation is at least 15\%) in the analysis are shown. Species codes: Amarcri - Amaranthus crispus, Digisan - Digitaria sanguinalis, Echicru - Echinochloa crus-galli, Loliper - Lolium perenne, Matrcha - Matricaria chamomilla, Oxalcor - Oxalis corniculata, Planmaj - Plantago major, Polyavi - Polygonum aviculare, Portole - Portulaca oleracea, Setavir - Setaria viridis, Trifrep - Trifolium repens, Verboff - Verbena officinalis 


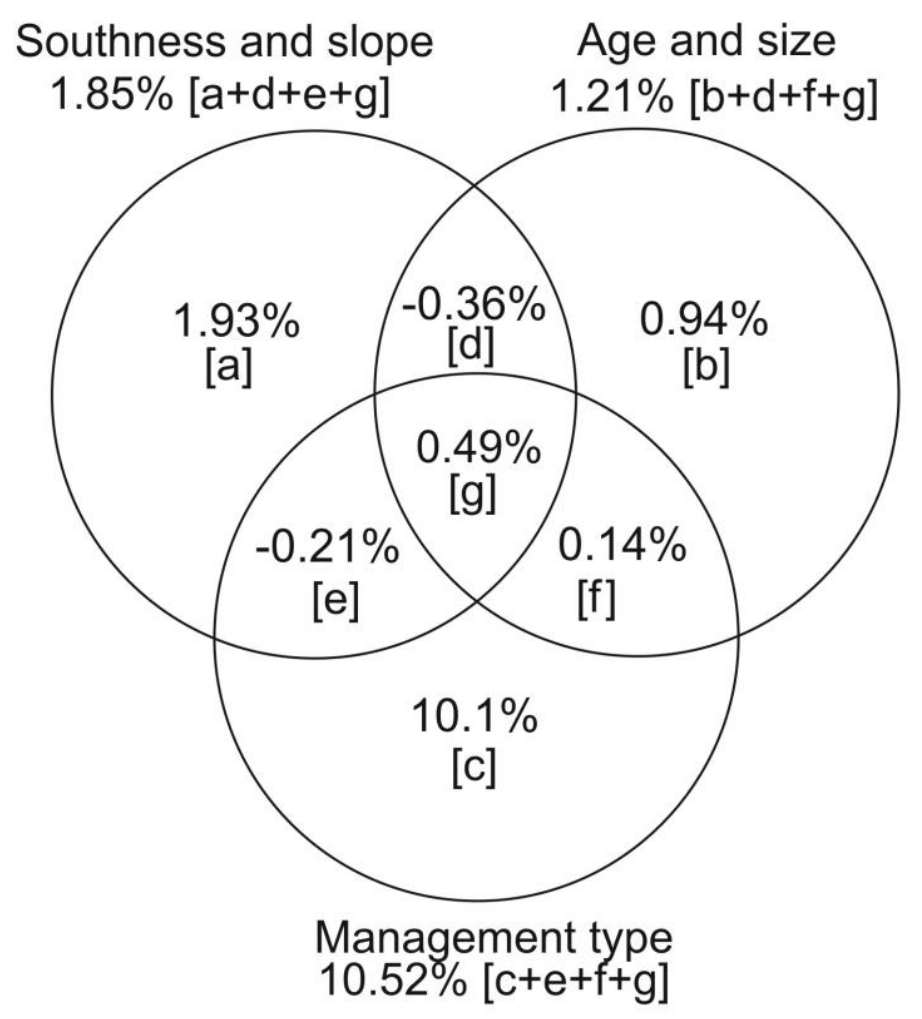

Fig. 6 Percentage contributions of three groups of explanatory variables to the variation in weed-species composition, identified using variation partitioning. Variation components [a], [b] and [c] are unique contributions of each of the three groups of variables; components [d], [e] and [f] are shared contributions of two groups of variables and [g] is the shared contribution of all the three groups of variables. Unexplained (residual) variation. Percentage values correspond to $\mathrm{R}^{2} \mathrm{~s}$ adjusted according to Peres-Neto et al. (2006) 